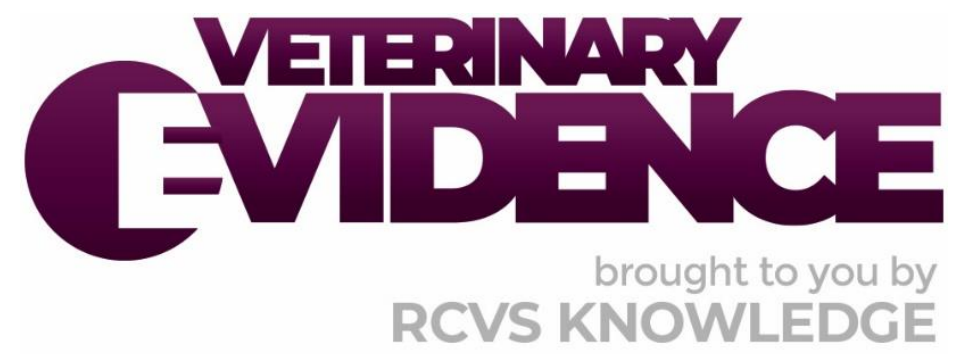

\title{
Do papillomaviruses cause feline cutaneous squamous cell carcinoma?
}

\section{A Knowledge Summary by}

\begin{abstract}
Alexander Teh Student ${ }^{1 *}$
Mark Krockenberger BSc (Vet) BVSc GradCertEdStud(Higher Ed.) PhD FANZCVS (Veterinary Anatomical Pathology) ${ }^{1}$

\footnotetext{
${ }^{1}$ Sydney School of Veterinary Science, B14 - McMaster Building, The University of Sydney, NSW 2006 Australia

*Corresponding Author (alexander.j.teh@gmail.com)
}

ISSN: 2396-9776

Published: 16 Sep 2021

in: The Veterinary Evidence journal Vol 6, Issue 3

DOI: https://doi.org/10.18849/ve.v6i3.402

Reviewed by: Julia Beatty (BSc(hons) BVetMed PhD FANZCVS (feline med) GradCertEd (Higher Ed) FRCVS GAICD) and John Munday (BVSc PhD DSc Diplomate ACVP)

Next Review Date: 31 Mar 2023 


\section{KNOWLEDGE SUMMARY}

\section{PICO question}

In cats infected with papillomavirus, is the risk of developing feline cutaneous squamous cell carcinoma greater than cats that are not infected with papillomavirus?

\section{Clinical bottom line}

\section{Category of research question}

Risk

\section{The number and type of study designs reviewed}

Eleven papers were critically reviewed, nine were case-control studies and two were experimental in vitro studies

\section{Strength of evidence}

\section{Moderate}

\section{Outcomes reported}

Infection of feline epithelial skin cells with Felis catus papillomavirus type 2 (FcaPV-2) is a risk factor for the development of feline cutaneous squamous cell carcinoma. The pathogenesis of FcaPV- 2 infection and neoplastic transformation into malignant cells shares similar pathways to the human papillomavirus (HPV) model of pathogenesis and carcinogenesis with some differences

\section{Conclusion}

In conclusion, there is moderate strength of evidence in the literature to support a role of FcaPV-2 in the development of cutaneous squamous cell carcinomas in cats. Therefore, prevention of infection with FcaPV-2 should prevent some cancers

\section{How to apply this evidence in practice}

The application of evidence into practice should take into account multiple factors, not limited to: individual clinical expertise, patient's circumstances and owners' values, country, location or clinic where you work, the individual case in front of you, the availability of therapies and resources.

Knowledge Summaries are a resource to help reinforce or inform decision making. They do not override the responsibility or judgement of the practitioner to do what is best for the animal in their care.

\section{Clinical Scenario}

Feline cutaneous squamous cell carcinomas (SCC) are considered to be the most common malignant skin neoplasm of cats and represent approximately 15\% of all feline skin neoplasms (O'Neill et al., 2011; Munday et al., 2009; Murphy, 2013; and Miller et al., 1991). Recent research has found evidence to suggest that feline papillomaviruses (in particular Felis catus papillomavirus type 2 (FcaPV-2)) are oncogenic, actively contributing to the development of feline SCC, similar to human papillomaviruses (HPV) and cervical cancer (O'Neill et al., 2011; Murphy, 2013; Oh et al., 2018; Munday \& Aberdein, 2012; Altamura et al., 2016b; Geisseler et al., 2016; Munday et al., 2019; and Munday et al., 2008). Given the high prevalence of SCC in the feline population and 
the suspected oncogenic link between FcaPV-2 and the development of SCC, it is worth considering whether prevention of papillomaviral infections in cats can become a novel method to reduce the risk and prevalence of SCC (Thomson et al., 2019). However, before recommending prevention of papillomaviral infections to reduce the risk of SCC, it is important to be certain that FcaPV-2 has a causative role in SCC development and is not simply detected as an incidental infection due to the SCC providing a more permissive environment for the virus.

\section{The evidence}

Nine of the studies included in this review were case-control studies which provide moderate levels of evidence to assess whether or not FCPV-2 promotes the development of SCC according to the hierarchy of evidence (Costantino et al., 2015; and Song \& Chung, 2010). The two remaining studies included in this review were experimental in vitro studies.

In vitro methods utilising cultured epithelial cells may not truly be representative of the molecular pathways that occur in a live animal (Froehlich \& Salar-Behzadi, 2014; and Sauer et al., 2013). Thus, extrapolation of the findings from in vitro methodologies to in vivo scenarios may not be fully accurate because the cultured cells are independent of the tissue environment that skin epithelial cells would normally exist in.

A common disadvantage across many of the studies included in this review were small sample sizes, ultimately weakening the statistical power of the evidence (Brown, 2012).

Altogether, the findings from all 11 studies were consistent however, mostly provided evidence of moderate strength to support the research question due to the study designs, small sample sizes and in vitro to in vivo extrapolation.

\section{Summary of the evidence}

\begin{tabular}{|c|c|}
\hline \multicolumn{2}{|l|}{ Nespeca et al. (2006) } \\
\hline Population: & $\begin{array}{l}\text { Formalin-fixed paraffin-embedded (FFPE) feline skin tissue samples } \\
\text { including invasive squamous cell carcinoma (ISCC), bowenoid in situ } \\
\text { carcinoma (BISC) and non-neoplastic skin. Samples were obtained } \\
\text { from the University of Saskatchewan (Canada), the Institute of } \\
\text { Pathology and Genetics (Belgium), Rest Associates (UK) and the } \\
\text { University of Bern (Switzerland). }\end{array}$ \\
\hline Sample size: & 22 FFPE ISCC, 21 BISC and 11 non-neoplastic skin \\
\hline Intervention details: & $\begin{array}{l}\text { DNA was extracted from each FFPE sample for polymerase chain } \\
\text { reaction (PCR) testing. This included two amplifications: } \\
\text { 1) to amplify DNA specific to feline papillomavirus type } 1 \\
\text { (FcaPV-1) and canine papillomavirus (CaPV) - the narrow- } \\
\text { range amplification; } \\
\text { 2) to amplify a broad spectrum of papillomaviruses across } \\
\text { multiple species - the broad-range amplification. }\end{array}$ \\
\hline Study design: & Case-control study \\
\hline Outcome studied: & $\begin{array}{l}\text { Presence or absence of papillomaviral DNA (narrow-range and } \\
\text { broad-range) within the FFPE samples. }\end{array}$ \\
\hline $\begin{array}{l}\text { Main findings: } \\
\text { (relevant to PICO question): }\end{array}$ & $\begin{array}{l}\text { - Narrow-range amplification of FcaPV-1 and CaPV DNA } \\
\text { yielded positive results in one BISC sample, and negative } \\
\text { results in all other lesions. } \\
\text { Broad-range amplification of PV DNA yielded positive results in } \\
\text { five BISCs and four SCC lesions. }\end{array}$ \\
\hline
\end{tabular}




\begin{tabular}{|c|c|}
\hline & - No PV DNA was detected in any of the non-neoplastic controls. \\
\hline Limitations: & $\begin{array}{l}\text { - This study utilised PCR in order to demonstrate an association } \\
\text { between cutaneous SCC and PV. However, amplification of DNA } \\
\text { within a lesion does not necessarily prove an oncogenic link, } \\
\text { merely an association. PV can still be isolated from a high } \\
\text { proportion of healthy cats (Thomson et al., 2016; and Munday } \\
\text { \& Kiupel, 2010). PCR alone cannot differentiate whether the } \\
\text { presence of PV in SCC lesions is a contaminant, transient } \\
\text { infection or an active carcinogen (Hoggard et al., 2018). } \\
\text { - Formalin fixation of tissues can fracture DNA which may } \\
\text { interfere or complicate PCR amplification of PV DNA, especially } \\
\text { if only small quantities of PV DNA are present (Little et al., } \\
\text { 2006). } \\
\text { - Difficult to control or assess the impact of co-factors and co- } \\
\text { carcinogens which may potentially influence the results. } \\
\text { - Small sample size. }\end{array}$ \\
\hline
\end{tabular}

Munday et al. (2007)

\begin{tabular}{|c|c|}
\hline Population: & $\begin{array}{l}\text { FFPE feline BISC lesions. FFPE samples were obtained from the } \\
\text { Diagnostic Center for Population and Animal Health at Michigan State } \\
\text { University, or New Zealand Veterinary Pathology Ltd. }\end{array}$ \\
\hline Sample size: & 18 FFPE BISC and 18 FFPE non-SCC tissue samples \\
\hline Intervention details: & $\begin{array}{l}\text { - DNA was extracted from the FFPE samples for PCR. } \\
\text { - PCR was used to amplify PV DNA in the FFPE samples using two } \\
\text { consensus primer sets that detect a broad range of cutaneous } \\
\text { papillomaviruses in both humans and animals. } \\
\text { - Six of the amplicons were sequenced. }\end{array}$ \\
\hline Study design: & Case-control study \\
\hline Outcome studied: & Presence or absence; and type of PV DNA using PCR and sequencing. \\
\hline $\begin{array}{l}\text { Main findings: } \\
\text { (relevant to PICO question): }\end{array}$ & $\begin{array}{l}\text { - PV DNA was amplified in } 11 \text { of the } 18 \text { BISC samples. } \\
\text { - } \quad \text { In DNA was not amplified in any of the non-SCC samples. } \\
\text { homologous with a papillomaviral strain that caused multiple } \\
\text { cutaneous SCCs in a human; and the other five were weakly } \\
\text { homologous to HPV type } 17 \text {. }\end{array}$ \\
\hline Limitations: & $\begin{array}{l}\text { - This study utilised PCR in order to demonstrate an association } \\
\text { between feline BISCS and PV. However, amplification of DNA } \\
\text { within a lesion does not necessarily prove an oncogenic link, } \\
\text { merely an association. PV can still be isolated from a high } \\
\text { proportion of healthy cats (Thomson et al., 2016; and Munday } \\
\text { \& Kiupel, 2010). PCR alone cannot differentiate whether the } \\
\text { presence of PV in BISCs is a contaminant, transient infection or } \\
\text { an active carcinogen (Hoggard et al., 2018). } \\
\text { - Formalin fixation of tissues can fracture DNA which may } \\
\text { interfere or complicate PCR amplification of PV DNA, especially } \\
\text { if only small quantities of PV DNA are present (Little et al., } \\
\text { 2006). } \\
\text { - Difficult to control or assess the impact of co-factors and co- } \\
\text { carcinogens which may potentially influence the results. } \\
\text { - Small sample size. }\end{array}$ \\
\hline
\end{tabular}




\begin{tabular}{|c|c|}
\hline \multicolumn{2}{|l|}{ Munday et al. (2008) } \\
\hline Population: & $\begin{array}{l}\text { FFPE biopsy submissions to the New Zealand Veterinary Pathology } \\
\text { diagnostic laboratory, or to the Diagnostic Center for Population and } \\
\text { Animal Health, Michigan State University. }\end{array}$ \\
\hline Sample size: & 40 SCC biopsies, and 17 non-SCC biopsies \\
\hline Intervention details: & $\begin{array}{l}\text { - SCC FFPE samples were divided into two groups -BISC and } \\
\text { invasive SCC by a board-certified pathologist. } \\
\text { DNA was extracted from the tissue samples and nested PCR } \\
\text { was performed with two amplifications - the first one was } \\
\text { to amplify a DNA fragment found in a wide range of } \\
\text { papillomaviruses across multiple species, including cats. The } \\
\text { second one was to amplify a DNA fragment in a } \\
\text { papillomavirus that was previously found in five feline BISC } \\
\text { lesions in another study (Munday et al., 2007). }\end{array}$ \\
\hline Study design: & Case-control study \\
\hline Outcome studied: & $\begin{array}{l}\text { Amplification of papillomaviral DNA in SCC and non-SCC FFPE tissue } \\
\text { samples using nested PCR. }\end{array}$ \\
\hline $\begin{array}{l}\text { Main findings: } \\
\text { (relevant to PICO question): }\end{array}$ & $\begin{array}{l}\text { Papillomaviral DNA was detected significantly more frequently in } \\
\text { feline cutaneous SCC lesions than non-SCC lesions }(P<0.001) \text {. }\end{array}$ \\
\hline Limitations: & $\begin{array}{l}\text { - Papillomaviral DNA can still be isolated from a proportion of } \\
\text { healthy cats (Thomson et al., 2016; and Munday \& Kiupel, } \\
\text { 2010). PCR alone cannot differentiate whether the presence } \\
\text { of PV in SCC lesions is a contaminant, transient infection or } \\
\text { an active carcinogen (Hoggard et al., 2018). } \\
\text { - Formalin fixation of tissues can fracture DNA which may } \\
\text { interfere or complicate PCR amplification of PV DNA, } \\
\text { especially if only small quantities of PV DNA are present } \\
\text { (Little et al., 2006). } \\
\text { - Difficult to control or assess the impact of co-factors and co- } \\
\text { carcinogens which may potentially influence the results. } \\
\text { - Small sample size. }\end{array}$ \\
\hline
\end{tabular}

\begin{tabular}{|c|c|}
\hline Population: & $\begin{array}{l}\text { FFPE feline tissue samples of SCC, BISC, feline viral plaques and } \\
\text { trichoblastoma lesions. Samples were collected from archives at } \\
\text { Massey University Veterinary Pathology diagnostic lab, Gribbles } \\
\text { Veterinary Pathology and Cornell University. }\end{array}$ \\
\hline Sample size: & $\begin{array}{l}18 \text { SCCs, } 14 \text { BISCs, } 14 \text { trichoblastomas and } 14 \text { feline viral plaque FFPE } \\
\text { tissue samples }\end{array}$ \\
\hline Intervention details: & $\begin{array}{l}\text { - SCC FFPE samples were divided into UV-exposed areas } \\
\text { (pinna or nasal planum) and UV-protected areas (other areas } \\
\text { of the body). } \\
\text { DNA was extracted from the FFPE samples for PCR using two } \\
\text { amplification reactions: firstly to amplify DNA specific to } \\
\text { Felis catus papillomavirus } 2 \text { (FcaPV-2); and the second was } \\
\text { to amplify papillomaviral DNA from a broad range of species. } \\
\text { The negative control utilised DNA from a bovine papilloma. }\end{array}$ \\
\hline
\end{tabular}




\begin{tabular}{|c|c|}
\hline & $\begin{array}{l}\text { - Immunohistochemistry (IHC) was performed on the FFPE } \\
\text { samples to measure the intensity of immunostaining for p16 } \\
\text { in the tissues. }\end{array}$ \\
\hline Study design: & Case-control study \\
\hline Outcome studied: & $\begin{array}{l}\text { - Presence or absence of FcaPV-2 and PV DNA using PCR. } \\
\text { - p16 levels in the FFPE lesions based on intensity of } \\
\text { immunostaining. }\end{array}$ \\
\hline $\begin{array}{l}\text { Main findings: } \\
\text { (relevant to PICO question): }\end{array}$ & $\begin{array}{l}\text { - FcaPV-2 DNA was amplified from } 12 \text { of the } 18 \text { SCCs (all seven } \\
\text { UV-protected lesions, and five of } 11 \text { UV-exposed lesions), } \\
\text { one trichoblastoma and all BISCs and feline viral plaque FFPE } \\
\text { tissue samples. } \\
\text { - Increased p16 immunostaining was detected in all BISCs, } \\
\text { feline viral plaques and UV-protected SCC lesions. In } \\
\text { contrast, little p16 immunostaining was observed in UV- } \\
\text { exposed SCC and trichoblastoma lesions. } \\
\text { p16 immunostaining was significantly less intense in UV- } \\
\text { exposed SCC lesions compared to UV-protected SCC lesions } \\
(P<0.001) \text {. }\end{array}$ \\
\hline Limitations: & $\begin{array}{l}\text { - DNA was not extracted from six viral plaques. } \\
\text { - Formalin fixation of tissues can fracture DNA which may } \\
\text { interfere or complicate PCR amplification of PV DNA, } \\
\text { especially if only small quantities of PV DNA are present } \\
\text { (Little et al., 2006). } \\
\text { - The specificity of IHC testing to demonstrate a PV/FcaPV-2 } \\
\text { aetiology in cats has not been definitely shown and it is } \\
\text { possible that spontaneous mutations in a cell's DNA, not due } \\
\text { to PV infection, can lead to increases in p16 (Munday et al., } \\
\text { 2019). } \\
\text { Difficult to control or assess the impact of co-factors and co- } \\
\text { carcinogens which may potentially influence the results. } \\
\text { - Small sample size. }\end{array}$ \\
\hline
\end{tabular}

\begin{tabular}{|c|c|}
\hline al. (2011b) & \\
\hline Population: & $\begin{array}{l}\text { FFPE feline tissue samples of cutaneous SCC. SCC cases were } \\
\text { identified from archived databases at Veterinary Pathology } \\
\text { Diagnostic Laboratory, Massey University, New Zealand; and } \\
\text { Gribbles Veterinary Pathology, Australia. SCC cases that did not } \\
\text { include a description of the lesion site were excluded from the } \\
\text { study. }\end{array}$ \\
\hline Sample size: & 70 FFPE SCC tissue samples \\
\hline Intervention details: & $\begin{array}{l}\text { - Tissue samples were divided into two groups: } \\
\circ \quad \text { SCC lesions from UV protected skin (densely haired } \\
\text { areas - neck, digit, thigh and face); } \\
\text { non-UV protected skin (sparsely haired areas - eyelid, } \\
\text { third eyelid, pinna and nasal planum). } \\
\text { - DNA was extracted from the SCC tissue samples, and } \\
\text { conventional PCR was used to amplify papillomaviral DNA } \\
\text { (including FcaPV-2 specific DNA and papillomaviral DNA from } \\
\text { multiple other species). }\end{array}$ \\
\hline
\end{tabular}




\begin{tabular}{|c|c|}
\hline & $\begin{array}{l}\text { - IHC was performed on the SCC tissue samples using a mouse } \\
\text { anti-human p16 monoclonal antibody to detect increased p16. }\end{array}$ \\
\hline Study design: & Case-control study \\
\hline Outcome studied: & $\begin{array}{l}\text { - Presence/absence of FcaPV-2 from the FFPE SCC lesions based } \\
\text { on amplification of its DNA using conventional PCR. } \\
\text { - Increased p16 based on immunoreactivity levels in the SCC } \\
\text { lesions. Percentage of cells in the samples that exhibited } \\
\text { intense cytoplasmic and nuclear immunoreactivity was } \\
\text { estimated through the examination of five different x } 400 \text { fields } \\
\text { in each section. SCC lesions were considered to have increased } \\
\text { p16 if }>90 \% \text { of the cytoplasm or nuclei of the neoplastic cells } \\
\text { contained intense immunoreactivity against p16. }\end{array}$ \\
\hline $\begin{array}{l}\text { Main findings: } \\
\text { (relevant to PICO question): }\end{array}$ & $\begin{array}{l}\text { - Papillomaviral DNA was identified and amplified in } 38 / 70 \text { SCC } \\
\text { cases ( } 54 \%) \text {. } \\
\text { - } \quad \text { FcaPV-2 specific DNA was amplified in } 33 / 70 \text { SCC cases }(47 \%) \text {. } \\
\text { - } \quad \text { Papillomaviral DNA was amplified significantly more frequently } \\
\text { in SCCs with increased p16 compared to SCCs that did not have } \\
\text { increased p16 }(\mathrm{P}<0.001) \text {. Thus, increased p16 were associated } \\
\text { with the presence of papillomaviral DNA in feline cutaneous } \\
\text { SCC lesions in this study }(\mathrm{P}<0.001) \text {. }\end{array}$ \\
\hline Limitations: & $\begin{array}{l}\text { - No comparisons to normal/non-SCC samples (only SCC tissue } \\
\text { samples were included in this study). This would have allowed } \\
\text { for a more effective comparison, as it would serve as a negative } \\
\text { control. Papillomaviral DNA can also be amplified from the skin } \\
\text { of normal, healthy cats (Munday \& Kiupel, 2010; and Thomson } \\
\text { et al., 2016). } \\
\text { - Determination of increased p16 relied on subjective estimation } \\
\text { rather than objective measurement. It relied on the estimation } \\
\text { of the percentage of increased immunoreactivity levels against } \\
\text { p16 through observation of cytoplasmic and nuclear changes. } \\
\text { - Formalin fixation of tissues can fracture DNA which may } \\
\text { interfere or complicate PCR amplification of PV DNA, especially } \\
\text { if only small quantities of PV DNA are present (Little et al., } \\
\text { 2006). } \\
\text { The specificity of IHC testing to demonstrate a PV/FcaPV-2 } \\
\text { aetiology in cats has not been definitely shown and it is } \\
\text { possible that spontaneous mutations in a cell's DNA, not due to } \\
\text { PV infection, can lead to increases in p16 (Munday et al., 2019). } \\
\text { - Difficult to control or assess the impact of co-factors and co- } \\
\text { carcinogens which may potentially influence the results. }\end{array}$ \\
\hline
\end{tabular}

O’Neill et al. (2011)

\begin{tabular}{|r|l|}
\hline Population: & $\begin{array}{l}\text { FFPE feline pre-malignant and invasive SCC lesions from both } \\
\text { cutaneous and non-cutaneous sites. }\end{array}$ \\
\hline Sample size: & $\begin{array}{l}\text { 126 FFPE SCC lesions. This included: } 12 \text { actinic keratosis (AK), 22 } \\
\text { BISCs, 39 cutaneous SCCs, 35 non-cutaneous SCCs, 13 cutaneous } \\
\text { dysplastic lesions and 5 carcinoma in situ lesions. }\end{array}$ \\
\hline Intervention details: & $\begin{array}{l}\text { SCC samples were separated into three categories - } \\
\text { dysplasia, carcinoma in situ and SCC. }\end{array}$ \\
\hline
\end{tabular}




\begin{tabular}{|c|c|}
\hline & $\begin{array}{l}\text { - PV DNA was extracted from the FFPE samples for PCR and } \\
\text { direct sequencing. A FFPE sample of an oral canine } \\
\text { papilloma was used as the positive control. }\end{array}$ \\
\hline Study design: & Case-control study \\
\hline Outcome studied: & $\begin{array}{l}\text { Presence or absence; and type of PV DNA using PCR and direct } \\
\text { sequencing. }\end{array}$ \\
\hline $\begin{array}{l}\text { Main findings: } \\
\text { (relevant to PICO question): }\end{array}$ & $\begin{array}{l}\text { - PV DNA was amplified in } 20 / 126 \text { SCC samples ( } 16 \% \text { of the } \\
\text { total sample size). } \\
\text { - PV DNA was amplified in } 9 / 39 \text { cutaneous SCC samples. } \\
\text { - } \quad \text { PV DNA was amplified in } 7 / 22 \mathrm{BISC} \text { samples. } \\
\text { - } 50 \% \text { of the PV DNA sequenced was most similar to the HPV } \\
\text { genus betapapillomavirus. } \\
\text { - The other } 50 \% \text { of the PV DNA sequenced was most similar to } \\
\text { FcaPV-2. }\end{array}$ \\
\hline Limitations: & $\begin{array}{l}\text { - This study utilised PCR in order to demonstrate an } \\
\text { association between feline SCC lesions and PV. However, } \\
\text { amplification of DNA within a lesion does not necessarily } \\
\text { prove an oncogenic link, merely an association. PV can still } \\
\text { be isolated from a high proportion of healthy cats (Thomson } \\
\text { et al., 2016; and Munday \& Kiupel, 2010). PCR alone cannot } \\
\text { differentiate whether the presence of PV in SCC lesions is a } \\
\text { contaminant, transient infection or an active carcinogen } \\
\text { (Hoggard et al., 2018). } \\
\text { - Formalin fixation of tissues can fracture DNA which may } \\
\text { interfere or complicate PCR amplification of PV DNA, } \\
\text { especially if only small quantities of PV DNA are present } \\
\text { (Little et al., 2006). } \\
\text { Difficult to control or assess the impact of co-factors and co- } \\
\text { carcinogens which may potentially influence the results. }\end{array}$ \\
\hline
\end{tabular}

Munday \& Aberdein (2012)

\begin{tabular}{|r|l|}
\hline Population: & $\begin{array}{l}\text { FFPE feline viral plaques, BISCs, and invasive SCCs. FFPE samples } \\
\text { were taken from Veterinary Pathology Diagnostic Laboratory, } \\
\text { Massey University, New Zealand; and Gribbles Veterinary Pathology, } \\
\text { Australia archives. }\end{array}$ \\
\hline Sample size: & $\begin{array}{l}30 \text { SCC (19 from UV-exposed skin, } 11 \text { from UV-protected skin), } 10 \\
\text { BISC, and five feline viral plaque tissue samples }\end{array}$ \\
\hline Intervention details: & $\begin{array}{l}\text { SCC tissues were grouped into UV-protected or UV-exposed } \\
\text { areas according to their location on their body. UV- } \\
\text { protected areas included the thigh, digit, face and neck. UV- } \\
\text { exposed areas included the eyelid, third eyelid, pinna and } \\
\text { nasal planum. } \\
\text { DNA was extracted from the FFPE samples for PCR. } \\
\text { PCR was used to amplify two types of PV DNA: DNA specific } \\
\text { to FcaPV-2 and papillomaviral DNA from multiple host } \\
\text { species. The positive control involved the use of DNA from a } \\
\text { feline viral plaque, and the negative control involved the use } \\
\text { of DNA from a bovine fibropapilloma. }\end{array}$ \\
&
\end{tabular}




\begin{tabular}{|c|c|}
\hline & $\begin{array}{l}\text { - } \mathrm{IHC} \text { was performed on the FFPE samples to detect } \\
\text { retinoblastoma (pRb), p16 and p53. }\end{array}$ \\
\hline Study design: & Case-control study \\
\hline Outcome studied: & $\begin{array}{l}\text { - Presence or absence of PV DNA in the FFPE tissue samples } \\
\text { using PCR amplification. } \\
\text { - Presence or absence of p53 and pRb immunostaining using } \\
\text { IHC. } \\
\text { - Normal or increased levels of p16 immunostaining using IHC. }\end{array}$ \\
\hline $\begin{array}{l}\text { Main findings: } \\
\text { (relevant to PICO question): }\end{array}$ & $\begin{array}{l}\text { - PV DNA was amplified from all viral plaques, all BISCs, and } \\
15 \text { SCC tissues ( } 50 \% \text { of SCC lesions contained PV DNA). } \\
\text { - } \text { Of the } 30 \text { samples that contained PV DNA, } 29 \text { of those } \\
\text { contained DNA specific to FcaPV-2. } \\
\text { - Reduced pRb immunoreactivity was more frequent in tissues } \\
\text { that contained PV DNA compared to tissues without PV DNA } \\
\text { (P<0.001). This included } 13 \text { SCCs, } 5 \text { viral plaques and eight } \\
\text { BISCs. } \\
\text { - Increased p16 levels were detected more frequently in } \\
\text { lesions that contained PV DNA compared to lesions that did } \\
\text { not contain PV DNA (P < 0.001). } \\
\text { - All lesions that had reduced pRb immunostaining also had a } \\
\text { simultaneous increase in p16 immunostaining. } \\
\text { No significant difference in the frequency of p53 } \\
\text { immunostaining and the presence or absence of PV DNA (P = } \\
\text { 0.45). } \\
\text { - No significant difference in the frequency of p53 } \\
\text { immunostaining between lesions with increased p16 (P = } \\
\text { 0.227) or decreased pRb ( } p=0.183 \text { ). } \\
\text { Presence of PV DNA within feline neoplastic and } \\
\text { paraneoplastic cutaneous lesions was associated with } \\
\text { reduced pRb immunostaining. Reduced pRb was also } \\
\text { associated with increased p16. However, feline PVs do not } \\
\text { appear to degrade p53 (no significant association). }\end{array}$ \\
\hline Limitations: & $\begin{array}{l}\text { - Formalin fixation of tissues can fracture DNA which may } \\
\text { interfere or complicate PCR amplification of PV DNA, } \\
\text { especially if only small quantities of PV DNA are present } \\
\text { (Little et al., 2006). } \\
\text { - The specificity of IHC testing to demonstrate a PV/FcaPV-2 } \\
\text { aetiology in cats has not been definitely shown and it is } \\
\text { possible that spontaneous mutations in a cell's DNA, not due } \\
\text { to PV infection, can lead to increases in p16 (Munday et al., } \\
\text { 2019). } \\
\text { - Difficult to control or assess the impact of co-factors and co- } \\
\text { carcinogens which may potentially influence the results. } \\
\text { - Small sample size. }\end{array}$ \\
\hline
\end{tabular}




\begin{tabular}{|c|c|}
\hline \multicolumn{2}{|l|}{ Altamura et al. (2016a) } \\
\hline Population: & $\begin{array}{l}\text { Cell culture of Crandell-Rees feline kidney (CRFK) feline epithelial } \\
\text { cells expressing FcaPV-2 genes - E6E7, E6 and E7. CRFK cells were } \\
\text { obtained from the American Type Culture Collection (ATCC) cell } \\
\text { bank. }\end{array}$ \\
\hline Sample size: & $\begin{array}{l}\text { Cell culture of CRFK feline epithelial cells transfected with FcaPV-2 } \\
\text { genes - E6E7, E6 and E7 }\end{array}$ \\
\hline Intervention details: & $\begin{array}{l}\text { Western blotting (WB) analysis was performed on the CRFK } \\
\text { feline epithelial cells to determine the expression levels of } \\
\text { protein kinase B (Akt), and the mitogen-activated protein } \\
\text { kinases (MAPK), mitogen-activated protein kinase kinase } \\
\text { (MEK), extracellular signal-regulated kinase (ERK). WB } \\
\text { analysis would also detect their activated forms - pMEK, } \\
\text { pERK and pAkt. } \\
\text { - Ribonucleic acid (RNA) was then extracted from the CRFK } \\
\text { feline epithelial cells and reverse transcription (RT) was } \\
\text { performed to yield complementary DNA (cDNA). } \\
\text { The CDNA was then subjected to real-time quantitative PCR } \\
\text { (qPCR) on epidermal growth factor receptor (EGFR) } \\
\text { transcripts. }\end{array}$ \\
\hline Study design: & Experimental, in vitro study \\
\hline Outcome studied: & $\begin{array}{l}\text { - Levels of MEK, ERK, Akt and their activated forms: pMEK, } \\
\text { pERK and pAkt - in CRFK cell cultures expressing FcaPV-2 } \\
\text { genes. } \\
\text { - Levels of EGFR activation or overexpression in the CRFK cell } \\
\text { cultures expressing FcaPV-2 genes. }\end{array}$ \\
\hline $\begin{array}{l}\text { Main findings: } \\
\text { (relevant to PICO question): }\end{array}$ & $\begin{array}{l}\text { - Total levels of MEK, ERK and Akt were equal and } \\
\text { unincreased amongst all cell lines. } \\
\text { - Expression of FcaPV-2 E6 was associated with increased } \\
\text { levels of pMEK, pERK and pAkt levels compared to control } \\
\text { cells. } \\
\text { - No significant differences in EGFR gene expression were } \\
\text { detected amongst all cell lines. This suggests that FcaPV-2 E6 } \\
\text { oncogene causes activation of MAPK and Akt pathways } \\
\text { independent of EGFR activation/overexpression. }\end{array}$ \\
\hline Limitations: & $\begin{array}{l}\text { - This is a completely in vitro study which provides a challenge } \\
\text { to extrapolate the results to living cats. } \\
\text { - Whilst the study utilised feline epithelial cells, these cells are } \\
\text { independent of the tissue environment that skin epithelial } \\
\text { cells would be. As such, the molecular pathways examined in } \\
\text { this study may not accurately represent the molecular } \\
\text { pathways in skin epithelial cells. } \\
\text { Difficult to control or assess the impact of co-factors and co- } \\
\text { carcinogens which may potentially influence the results. }\end{array}$ \\
\hline
\end{tabular}




\begin{tabular}{|c|c|}
\hline \multicolumn{2}{|l|}{ Altamura et al. (2016b) } \\
\hline Population: & $\begin{array}{l}\text { 1. In vitro Part: Cell culture of CRFK feline epithelial cells } \\
\text { transfected with FcaPV-2 genes - E6E7, E6 and E7. Ultraviolet-B } \\
\text { (UVB)-treated CRFK cells were also utilised in a separate } \\
\text { intervention group. CRFK cells were obtained from ATCC cell } \\
\text { bank. } \\
\text { 2. In vivo Part: Feline tissue biopsies from hospitalised cats at the } \\
\text { Veterinary Teaching Hospital, University of Naples; and private } \\
\text { veterinary practices in Southern Italy. }\end{array}$ \\
\hline Sample size: & $\begin{array}{l}\text { In vitro Part: CRFK feline epithelial cells transfected with FcaPV-2 } \\
\text { oncogenes: E6E7, E6 and E7. } \\
\text { In vivo Part: Eight cutaneous SCCs, two non-SCC skin lesions, one oral } \\
\text { SCC and } 10 \text { normal skin samples. }\end{array}$ \\
\hline Intervention details: & $\begin{array}{l}\text { In vitro Part } \\
\text { - } \text { RNA was extracted from the CRFK feline epithelial cells and RT } \\
\text { - } \text { performed to yield cDNA. } \\
\text { (qPCR) for feline p53, glyceraldehyde 3-phosphate } \\
\text { dehydrogenase (GAPDH), Bcl-XI and Cdc2. } \\
\text { - CRFK cells for UVB treatment were irradiated in phosphate- } \\
\text { buffered saline (PBS) and harvested after } 8 \text { hours. } \\
\text { - WB analysis was then performed utilising antibodies against } \\
\text { p53, p21, Caspase 3, Bax, Bak, pRb, Cyclin A, Cdc2, Glutathione- } \\
\text { S-Transferase (GST) and beta-actin. } \\
\text { - FcaPV-2 and HPV16 E6 and E7 genes were then cloned in a GST } \\
\text { fusion vector for GST pull-down assays. The molecular } \\
\text { complexes were then analysed by WB for the detection of p53, } \\
\text { pRb and GST tags. } \\
\text { In vivo Part } \\
\text { - DNA was extracted from the tissue biopsies for PCR } \\
\text { amplification of a specific fragment of the FcaPV-2 L1 gene. } \\
\text { RNA was extracted from the tissue biopsies and RT performed } \\
\text { to yield cDNA. } \\
\text { - The cDNA was then subjected to PCR to amplify specific } \\
\text { fragments of FcaPV-2 E2, E6 and E7 genes, and feline GAPDH. }\end{array}$ \\
\hline Study design: & $\begin{array}{l}\text { Experimental in vitro study (In vitro Part); and Case-control study (In } \\
\text { vivo Part) }\end{array}$ \\
\hline Outcome studied: & $\begin{array}{l}\text { In vitro Part } \\
\text { - Establish an in vitro model of the transformative properties of } \\
\text { FcaPV-2 E6 and E7 oncogenes and their impacts on the p53 and } \\
\text { pRb pathways, and UVB-induced apoptosis. } \\
\text { In vivo Part } \\
\text { - Expression of E6 and E7 oncogenes in SCC samples. } \\
\text { - Expression of E2 in SCC samples. }\end{array}$ \\
\hline $\begin{array}{l}\text { Main findings: } \\
\text { (relevant to PICO question): }\end{array}$ & $\begin{array}{l}\text { In vitro Part } \\
\text { - FcaPV-2 E6 bound to feline p53 based on the GST pull-down } \\
\text { assay. } \\
\text { - p53 levels were significantly decreased in the CRFK cells } \\
\text { expressing E6E7, E6 and E7 genes. }\end{array}$ \\
\hline
\end{tabular}




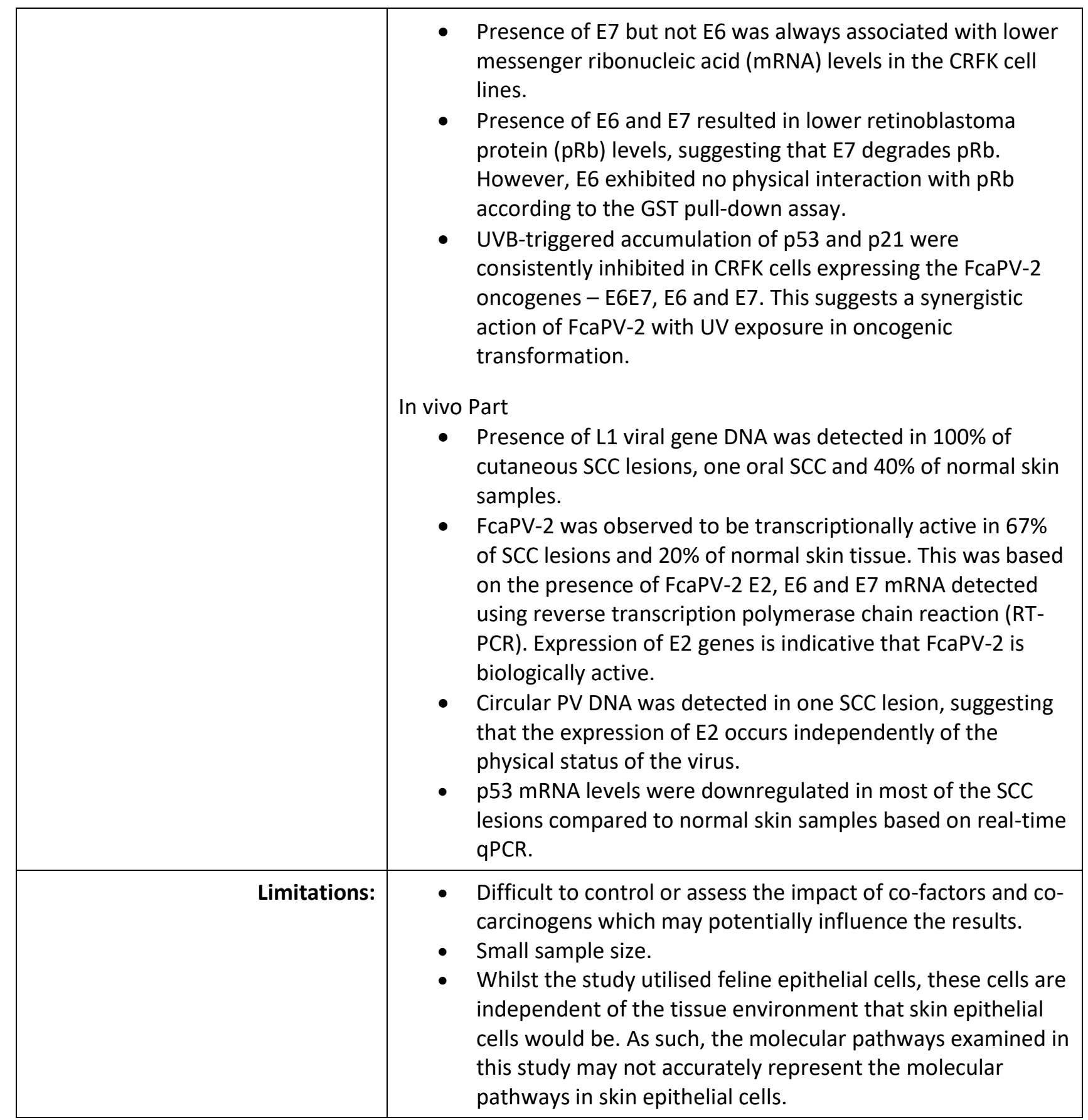

Thomson et al. (2016)

\begin{tabular}{|r|l|}
\hline Population: & $\begin{array}{l}\text { FFPE skin tissue samples, including SCC, papillomavirus-induced } \\
\text { premalignant lesions and normal skin. FFPE tissue samples were } \\
\text { sourced from the New Zealand Veterinary Pathology diagnostic } \\
\text { laboratory archives. }\end{array}$ \\
\hline Sample size: & 60 FFPE SCC, 10 pre-malignant and 10 normal skin tissue samples \\
\hline Intervention details: & $\begin{array}{l}\text { The SCC tissue samples were classified according to their } \\
\text { location - densely haired areas (neck, trunk, paw and face) } \\
\text { and sparsely haired areas (pinna, eyelids and nasal planum). } \\
\end{array}$ \\
& $\begin{array}{l}\text { RNA and DNA were extracted from each FFPE sample. } \\
\text { Real-time PCR was performed on the FFPE samples to } \\
\text { amplify FcaPV-2 DNA. }\end{array}$ \\
\hline
\end{tabular}




\begin{tabular}{|c|c|}
\hline & $\begin{array}{l}\text { - Real-time PCR was performed on the FFPE samples to } \\
\text { amplify FcaPV-2 E6 and E7 mRNA. } \\
\text { - IHC was then performed on the FFPE samples to detect p16 } \\
\text { immunostaining. }\end{array}$ \\
\hline Study design: & Case-control study \\
\hline Outcome studied: & $\begin{array}{l}\text { - Presence or absence of FcaPV-2 DNA in the FFPE lesions } \\
\text { based on real-time PCR amplification. } \\
\text { - Presence or absence of FcaPV-2 E6 and E7 mRNA oncogenes } \\
\text { in the FFPE lesions based on real-time PCR amplification. } \\
\text { - Presence of p16 based on immunostaining levels using IHC. }\end{array}$ \\
\hline $\begin{array}{l}\text { Main findings: } \\
\text { (relevant to PICO question): }\end{array}$ & 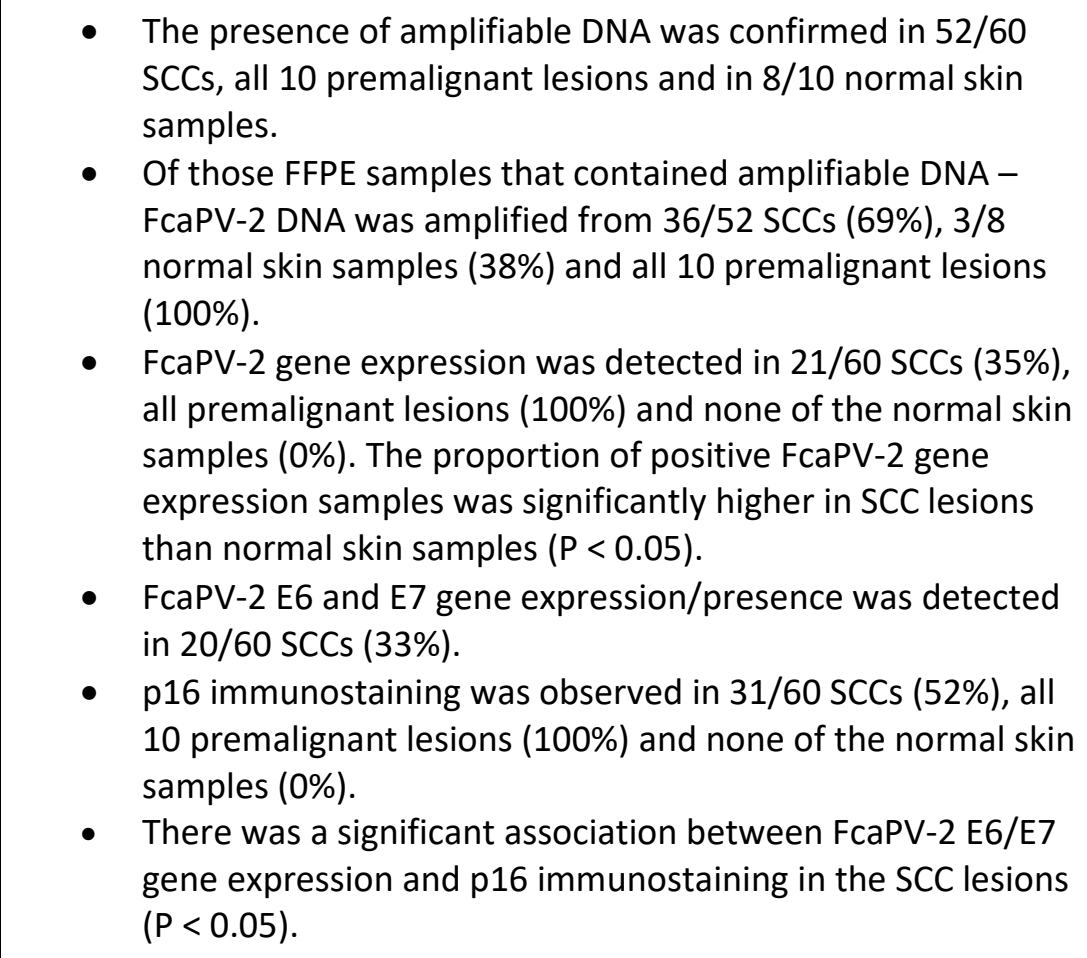 \\
\hline Limitations: & $\begin{array}{l}\text { - Formalin fixation of tissues can fragment DNA which may } \\
\text { interfere with or complicate PCR amplification of PV DNA, } \\
\text { especially if only small quantities of PV DNA are present } \\
\text { (Little et al., 2006). } \\
\text { - The specificity of IHC testing to demonstrate a PV/FcaPV-2 } \\
\text { aetiology in cats has not been definitively shown and it is } \\
\text { possible that spontaneous mutations in a cell's DNA, not due } \\
\text { to PV infection, can lead to increases in p16 (Munday et al., } \\
\text { 2019). } \\
\text { Difficult to control or assess the impact of co-factors and co- } \\
\text { carcinogens which may potentially influence the results. }\end{array}$ \\
\hline
\end{tabular}

Hoggard et al. (2018)

Population: FFPE feline tissue samples of cutaneous SCC and non-SCC cases. Samples were selected from archived biopsies from the North Carolina State College of Veterinary Medicine Anatomic Pathology Service, USA. Selection was based on the location of the lesion on the body (cutaneous lesions and UV protected/non-UV protected 


\begin{tabular}{|c|c|}
\hline & $\begin{array}{l}\text { skin), quality of the sample (no autolysis and adequate tissue } \\
\text { present), and whether there was intact bordering skin. }\end{array}$ \\
\hline Sample size: & 18 SCC tissue samples, and 10 non-SCC tissue samples \\
\hline Intervention details: & $\begin{array}{l}\text { - FFPE samples were divided into SCC lesion (positive control) } \\
\text { and non-SCC lesion (negative control) groups. SCC was } \\
\text { confirmed histologically by a board-certified veterinary } \\
\text { pathologist. } \\
\text { - Conventional PCR was performed on the FFPE tissues in } \\
\text { order to identify the presence of FcaPV-2 in the samples. } \\
\text { The positive control utilised gDNA from feline viral plaques, } \\
\text { whilst the negative control sample had no template DNA. } \\
\text { Colorimetric RNAscope in-situ hybridisation (ISH) was then } \\
\text { conducted to identify FcaPV-2 E6 and E7 mRNA in the FFPE } \\
\text { samples using targeting probes specific for the nucleic acid. }\end{array}$ \\
\hline Study design: & Case-control study \\
\hline Outcome studied: & $\begin{array}{l}\text { - Presence/absence of FcaPV-2 in the FFPE samples by } \\
\text { conventional PCR based on amplification of FcaPV-2 DNA. } \\
\text { - Identification and localisation of FcaPV-2 E6 and E7 mRNA in } \\
\text { the FFPE samples using colorimetric RNAscope ISH. } \\
\text { Identification and localisation of E6 and E7 mRNA is based } \\
\text { on positive hybridisation signals from the ISH test. }\end{array}$ \\
\hline $\begin{array}{l}\text { Main findings: } \\
\text { (relevant to PICO question): }\end{array}$ & $\begin{array}{l}\text { - FcaPV-2 DNA was amplified in 9/18 SCC samples ( } 50 \% \text { of SCC } \\
\text { lesions had FcaPV-2). } \\
\text { - Of those nine FcaPV-2 positive SCC samples - FcaPV-2 E6 } \\
\text { and E7 mRNA was detected in 5/9 of them. } 4 / 9 \text { of these } \\
\text { FcaPV-2 positive SCC samples did not contain E6 and E7 } \\
\text { mRNA. } \\
\text { - The other nine did not have either FcaPV-2 infection or } \\
\text { presence of E6 and E7 nucleic acid. Nine SCC cases did not } \\
\text { have FcaPV-2 DNA or the associated E6 and E7 mRNA. } \\
\text { - None of the } 10 \text { non-SCC samples returned any positive result } \\
\text { for FcaPV-2 E6 and E7 mRNA. } \\
\text { - FcaPV-2 E6 and E7 mRNA was detected and localised in 5/18 } \\
\text { SCC samples (28\%). }\end{array}$ \\
\hline Limitations: & $\begin{array}{l}\text { - RNAscope ISH has the potential to detect both RNA and } \\
\text { DNA. The study only used this method to detect E6 and E7 } \\
\text { mRNA. } \\
\text { - Formalin fixation of tissues can fragment DNA which may } \\
\text { interfere or complicate PCR amplification of PV DNA, } \\
\text { especially if only small quantities of PV DNA are present } \\
\text { (Little et al., 2006). } \\
\text { - Difficult to control or assess the impact of co-factors and co- } \\
\text { carcinogens which may potentially influence the results. } \\
\text { - Small sample size. }\end{array}$ \\
\hline
\end{tabular}


Feline papillomaviruses (especially Felis catus papillomavirus type 2 - FcaPV-2) have been suspected as a potential oncogenic factor in the development of feline cutaneous squamous cell carcinomas (SCC), similar to human papillomaviruses (HPV) (O'Neill et al., 2011; Murphy, 2013; Oh et al., 2018; Munday \& Aberdein, 2012; Altamura et al., 2016b; Geisseler et al., 2016; Munday et al., 2019; and Munday et al., 2008). The aim of this Knowledge Summary was to review the primary evidence available in order to assess the strength of evidence supporting FcaPV-2 involvement in SCC oncogenesis. This may open up a new pathway to reduce the incidence of the SCC cases by preventing PV infections, such as through vaccination (Thomson et al., 2019).

Early studies into this topic focused mainly on demonstrating an association between the presence of PV and SCC lesions (Munday et al., 2008; Munday et al., 2007; O'Neill et al., 2011; and Nespeca et al., 2006). This was primarily achieved through PCR amplification of PV DNA (including FcaPV-2) from SCC lesions (Munday et al., 2008; O'Neill et al., 2011; Munday et al., 2007; and Nespeca et al., 2006). Whilst a significant association was demonstrated between the presence of FcaPV-2 within SCC lesions, causation is not established by this evidence. FcaPV-2 is still isolated from a high proportion of normal and clinically healthy cats (Munday \& Kiupel, 2010; Thomson et al., 2016; and Munday et al., 2019). PCR alone cannot differentiate whether the presence of FcaPV-2 in SCC lesions is a contaminant, transient infection or an active carcinogen (Hoggard et al., 2018). Thus, whilst these studies were important to identify that initial significant association, they provided weak evidence to support whether FcaPV-2 is actively oncogenic in the malignant transformation of SCC.

Stronger evidence to support the oncogenic role of FcaPV-2 came from studies that aimed to demonstrate mechanisms that FcaPV-2 utilises in neoplastic transformation. These studies analysed either the effect of FcaPV-2 on host cell tumour suppressor genes and proteins - p16, p53 and retinoblastoma (pRb); and/or the oncogenic and transformative activity of FcaPV-2 viral proteins and E6/E7 oncogenes.

The roles of host cell tumour suppressor genes and proteins - p16, p53 and pRb - were investigated using immunohistochemistry in three studies included in this review (Munday \& Aberdein, 2012; Munday et al., 2011a; and Munday et al., 2011b). Increased p16 levels were significantly associated with the presence of PV DNA in SCC lesions (Munday \& Aberdein, 2012; Munday et al., 2011b; and Munday et al., 2011a). Additionally, elevated p16 levels were significantly associated with reductions in pRb in PV-infected cutaneous neoplastic lesions (including SCC); and decreases in pRb were significantly associated with presence of PV DNA in cutaneous lesions (Munday \& Aberdein, 2012). Interestingly, p53 levels were unaffected in PV-infected cutaneous neoplastic lesions (Munday \& Aberdein, 2012).

Accordingly, the transformative mechanisms of FcaPV-2 draw some similarities with HPV in that both PVs influence cell regulation by degrading and inactivating pRb (Munday \& Aberdein, 2012; and Munday et al., 2011a). p16 regulates cell division utilising a mechanism that is dependent on pRb, and thus decreased levels of pRb in turn results in increased p16 levels (Munday \& Aberdein, 2012; Coleman, 2010; and Parry et al., 1995). Even though p16 is a tumour suppressor protein, elevated levels in cells due to FcaPV-2 degradation of pRb will not cause tumour suppression because the function of p16 is dependent on pRb (Ohtani et al., 2004). However, unlike HPV, p53 is not degraded by FcaPV-2 (Munday \& Aberdein, 2012). These studies provided evidence that FcaPV-2 shares a similar transformative pathway to HPV, by disrupting the pRb/p16 cell regulation pathway, with the exception of p53 degradation.

If FcaPV-2 was actively involved in the oncogenesis of SCC, then it would be expected that the virus would be present in the lesion at high viral loads and with active transcription, especially of E6 and E7 genes, because their products can influence neoplastic transformation and cell proliferation (Wilczynski et al., 1998; and Thomson et al., 2016). In the HPV model of oncogenesis, a key event in malignant transformation involves the deregulation of PV E6 and E7 oncogenes, which are normally expressed within the suprabasal epidermal layers (Flores et al., 2000). Overexpression of PV E6/E7 oncogenes in the basal cells results in abnormal cell proliferation and the acquisition of new mutations which can ultimately progress to cancer (Isaacson Wechsler et al., 2012). 
Four studies included in this summary aimed to demonstrate how FcaPV-2 proteins and E6/E7 oncogenes are involved in the neoplastic transformation of cells into SCC lesions (Altamura et al., 2016b; Thomson et al., 2016; Altamura et al., 2016a; and Hoggard et al., 2018). These studies provided evidence to support the carcinogenic properties of FcaPV-2. Altamura et al. (2016a) and Altamura et al. (2016b) utilised in vitro models in their studies (specifically cultured feline kidney epithelial cells), which may mean that the results are somewhat challenging to extrapolate to living cats. Furthermore, whilst the studies utilised feline epithelial cells, these cells are independent of the tissue environment that skin epithelial cells would be. As such, the molecular pathways examined in these studies may not accurately represent the molecular pathways in skin epithelial cells and thus provide a moderate level of evidence to support the PICO question.

Thomson et al. (2016) demonstrated that transcriptionally active FcaPV-2 expressing E6/E7 oncogenes was present in one-third of the study's FFPE SCC sample size which was also significantly associated with increased p16 levels. Continuing on from those findings, Altamura et al. (2016b) showed in vivo that biologically active FcaPV-2 can express the oncogenic viral genes E2, E6 and E7 in FFPE SCC lesions; and the transformative effects of E6/E7 oncogenes in disrupting $\mathrm{p} 53$ and pRb pathways in vitro. This seemingly conflicts with findings by Munday \& Aberdein (2012) which found that FcaPV-2 does not degrade p53. A completely in vitro study by Altamura et al. (2016a) revealed a difference between the pathogenesis of FcaPV-2 and the HPV model of pathogenesis. FcaPV-2 E6 oncogene enhances the activation of MAPK and Akt pathways independently of EGFR expression, which contrasts with the HPV model of pathogenesis which is EGFR-dependent (Altamura et al., 2016a). MAPK is a key regulator of the Ras-MAPK signalling route which is involved in cellular proliferation, and Akt is involved in the inhibition of apoptosis (Ranieri et al., 2013). Hoggard et al. (2018) demonstrated the presence of E6/E7 $\mathrm{mRNA}$, and unregulated E6/E7 transcription in SCC lesions. This is a similar finding to the HPV model of pathogenesis (Hoggard et al., 2018; and Boscolo-Rizzo et al., 2016).

In conclusion, there is evidence in the literature to say with moderate confidence that FcaPV-2 is actively involved in carcinogenesis and the development of SCC. The pathogenesis of FcaPV-2 and neoplastic transformation processes share many similar characteristics with the HPV model of pathogenesis; however, they are not identical. 


\section{Methodology Section}

\begin{tabular}{|c|c|}
\hline \\
\hline $\begin{array}{l}\text { Search Strategy } \\
\text { Databases searched and dates } \\
\text { covered: }\end{array}$ & $\begin{array}{l}\text { CAB Abstracts via Web of Science (1910 - Present) } \\
\text { Medline via OvidSP (1946 - Present) } \\
\text { Web of Science Core Collection ( } 1900 \text { - Present) }\end{array}$ \\
\hline Search terms: & $\begin{array}{l}\text { CAB Abstracts: } \\
\text { 1. cat or cats or feline or felid or felids or felis catus } \\
\text { 2. papillomavirus or papillomaviridae or FcaPV } \\
\text { 3. skin or cutaneous } \\
\text { 4. squamous cell carcinoma or SCC } \\
\text { 5. } \# 1 \text { and } \# 2 \text { and } \# 3 \text { and \#4 } \\
\text { Medline: } \\
\text { 1. cat or cats or feline or felid or felids or felis catus or exp Cats } \\
\text { 2. FcaPV or papillomavirus or exp Papillomavirus Infections or } \\
\text { exp Papillomaviridae } \\
\text { 3. squamous cell carcinoma or exp Carcinoma, Squamous Cell } \\
\text { 4. skin or cutaneous } \\
\text { 5. \#1 and \#2 and \#3 and \#4 } \\
\text { Web of Science: } \\
\text { 1. cat or cats or feline or felid or felids or felis catus } \\
\text { 2. papillomavirus or papillomaviridae or FcaPV } \\
\text { 3. skin or cutaneous } \\
\text { 4. squamous cell carcinoma or SCC } \\
\text { 5. \#1 and \#2 and \#3 and \#4 }\end{array}$ \\
\hline Dates searches performed: & 31 Mar 2021 \\
\hline
\end{tabular}

\section{Exclusion / Inclusion Criteria}

Exclusion: Not relevant to the PICO question, non-feline species, study not able to be accessed, non-English studies, conference proceedings, literature reviews, case report/study, book chapters

Inclusion: Relevant to the PICO question, focuses on feline species, able to access the study, primary research studies, English studies 


\begin{tabular}{|c|c|c|c|c|c|c|c|c|}
\hline \multicolumn{9}{|c|}{ Search Outcome } \\
\hline Database & $\begin{array}{c}\text { Number of } \\
\text { results }\end{array}$ & $\begin{array}{c}\text { Excluded - } \\
\text { Not relevant } \\
\text { to PICO }\end{array}$ & $\begin{array}{l}\text { Excluded - } \\
\text { Non-feline } \\
\text { species }\end{array}$ & $\begin{array}{l}\text { Excluded - } \\
\text { Study cannot } \\
\text { be accessed }\end{array}$ & $\begin{array}{l}\text { Excluded - } \\
\text { Non-English } \\
\text { studies }\end{array}$ & $\begin{array}{c}\text { Excluded - } \\
\text { Conference } \\
\text { proceedings, } \\
\text { literature reviews, } \\
\text { case report/study, } \\
\text { book chapters }\end{array}$ & $\begin{array}{l}\text { Excluded - } \\
\text { Duplicates }\end{array}$ & $\begin{array}{c}\text { Total } \\
\text { relevant } \\
\text { papers }\end{array}$ \\
\hline CAB Abstracts & 41 & 19 & 2 & 0 & 4 & 7 & 0 & 2 \\
\hline Medline & 35 & 11 & 3 & 0 & 1 & 1 & 18 & 1 \\
\hline $\begin{array}{l}\text { Web of } \\
\text { Science }\end{array}$ & 53 & 25 & 4 & 1 & 0 & 4 & 18 & 1 \\
\hline \multicolumn{8}{|c|}{ Total relevant papers when duplicates removed } & 11 \\
\hline
\end{tabular}

Veterinary Evidence

ISSN:2396-9776

Vol 6, Issue 3

page | 18 of 22

DOI: https://doi.org/10.18849/ve.v6i3.402

next review date: 31 Mar 2023 
The authors declare no conflict of interest.

\section{REFERENCES}

1. Altamura, G., Corteggio, A. \& Borzacchiello, G. (2016a). Felis catus papillomavirus type 2 E6 oncogene enhances mitogen-activated protein kinases and Akt activation but not EGFR expression in an in vitro feline model of viral pathogenesis. Veterinary Microbiology. 195, 96DOI: https://doi.org/10.1016/i.vetmic.2016.09.013

2. Altamura, G., Corteggio, A., Pacini, L., Conte, A., Pierantoni, G. M., Tommasino, M., Accardi, R. \& Borzacchiello, G. (2016b). Transforming properties of Felis catus papillomavirus type 2 E6 and E7 putative oncogenes in vitro and their transcriptional activity in feline squamous cell carcinoma in vivo. 496, 1-8. DOI: https://doi.org/10.1016/i.virol.2016.05.017

3. Boscolo-Rizzo, P., Pawlita, M. \& Holzinger, D. (2015). From HPV-positive towards HPV-driven oropharyngeal squamous cell carcinomas. Cancer Treatment Reviews. 42, 24DOI: https://doi.org/10.1016/j.ctrv.2015.10.009

4. Brown, S. J. (2012). Evidence-based Nursing: The Research-practice Connection, Jones \& Bartlett Learning.

5. Coleman, J. F. (2010). Robbins and Cotran's Pathologic Basis of Disease, 8th Edition. The American Journal of Surgical Pathology. 34(1), 259- DOI: https://doi.org/10.1097/PAS.0B013E3181BC5F0F

6. Costantino, G., Montano, N. \& Casazza, G. (2015). When should we change our clinical practice based on the results of a clinical study? The hierarchy of evidence. Internal and Emergency Medicine. 10(6), 745- DOI: https://doi.org/10.1007/s11739-015-1230-8

7. Flores, E. R., Allen-Hoffmann, B. L., Lee, D. \& Lambert, P. F. (2000). The Human Papillomavirus Type 16 E7 Oncogene Is Required for the Productive Stage of the Viral Life Cycle. Journal of Virology. 74, 6622DOI: https://doi.org/10.1128/JVI.74.14.6622-6631.2000

8. Froehlich, E. \& Salar-Behzadi, S. (2014). Toxicological Assessment of Inhaled Nanoparticles: Role of in Vivo, ex Vivo, in Vitro, and in Silico International Journal of Molecular Sciences. 15(3), 4795-4822. DOI: https://doi.org/10.3390/ijms15034795

9. Geisseler, M., Lange, C. E., Favrot, C., Fischer, N., Ackermann, M. \& Tobler, K. (2016). Geno- and seroprevalence of Felis domesticus Papillomavirus type 2 (FdPV2) in dermatologically healthy cats. BMC Veterinary Research. 12, DOI: https://doi.org/10.1186/s12917-016-0776-7

10. Hoggard, N., Munday, J. S. \& Luff, J. (2018). Localization of Felis catus Papillomavirus Type 2 E6 and E7 RNA in Feline Cutaneous Squamous Cell Carcinoma. Veterinary Pathology. 55(3), 409DOI: https://doi.org/10.1177\%2F0300985817750456

11. Isaacson Wechsler, E., Wang, Q., Roberts, I., Pagliarulo, E., Jackson, D., Untersperger, C., Coleman, N., Griffin, H. \& Doorbar, J. (2012). Reconstruction of human papillomavirus type 16-mediated early-stage neoplasia implicates E6/E7 deregulation and the loss of contact inhibition in neoplastic progression. Journal of Virology. 86, 6358- DOI: https://doi.org/10.1128/ivi.07069-11

12. Little, S. E., Vuononvirta, R., Reis-Filho, J. S., Natrajan, R., Iravani, M., Fenwick, K., Mackay, A., Ashworth, A., Pritchard-Jones, K. \& Jones, C. (2006). Array CGH using whole genome amplification of fresh-frozen and formalin-fixed, paraffin-embedded tumor DNA. 87(2), 298-306.

DOI: https://doi.org/10.1016/i.ygeno.2005.09.019

13. Miller, M. A., Nelson, S. L., Turk, J. R., Pace, L. W., Brown, T. P., Shaw, D. P., Fischer, J. R. \& Gosser, H. S. (1991). Cutaneous Neoplasia in 340 Cats. Veterinary Pathology. 28(5), 389-

DOI: https://doi.org/10.1177\%2F030098589102800506

14. Munday, J. S. \& Aberdein, D. (2012). Loss of retinoblastoma protein, but not p53, is associated with the presence of papillomaviral DNA in feline viral plaques, Bowenoid in situ carcinomas, and squamous cell carcinomas. Veterinary Pathology. 49(3), 538- DOI: https://doi.org/10.1177\%2F0300985811419534 
15. Munday, J. S., French, A. F., Peters-Kennedy, J., Orbell, G. M. \& Gwynne, K. (2011a). Increased p16CDKN2A protein within feline cutaneous viral plaques, bowenoid in situ carcinomas, and a subset of invasive squamous cell carcinomas. Veterinary Pathology. 48(2), 460-

DOI: https://doi.org/10.1177\%2F0300985810374844

16. Munday, J. S., Gibson, I. \& French, A. F. (2011b). Papillomaviral DNA and increased p16CDKN2A protein are frequently present within feline cutaneous squamous cell carcinomas in ultraviolet-protected skin. Veterinary Dermatology. 22(4), 360- DOI: https://doi.org/10.1111/i.1365-3164.2011.00958.x

17. Munday, J. S., Howe, L., French, A., Squires, R. A. \& Sugiarto, H. (2009). Detection of papillomaviral DNA sequences in a feline oral squamous cell carcinoma. Research in Veterinary Science. 86(2), 359DOI: https://doi.org/10.1016/j.rvsc.2008.07.005

18. Munday, J. S. \& Kiupel, M. (2010). Papillomavirus-Associated Cutaneous Neoplasia in Mammals. Veterinary Pathology. 47(2), 254- DOI: https://doi.org/10.1177\%2F0300985809358604

19. Munday, J. S., Kiupel, M., French, A. F. \& Howe, L. (2008). Amplification of papillomaviral DNA sequences from a high proportion of feline cutaneous in situ and invasive squamous cell carcinomas using a nested polymerase chain reaction. Veterinary Dermatology. 19(5), 259DOI: https://doi.org/10.1111/j.1365-3164.2008.00685.x

20. Munday, J. S., Kiupel, M., French, A. F., Howe, L. \& Squires, R. A. (2007). Detection of papillomaviral sequences in feline Bowenoid in situ carcinoma using consensus primers. Veterinary Dermatology. 18(4), 241- DOI: https://doi.org/10.1111/j.1365-3164.2007.00600.x

21. Munday, J. S., Sharp, C. R. \& Beatty, J. A. (2019). Novel viruses: Update on the significance of papillomavirus infections in cats. Journal of Feline Medicine and Surgery. 21(5), 409DOI: https://doi.org/10.1177\%2F1098612X18808105

22. Murphy, S. (2013). Cutaneous Squamous Cell Carcinoma in the Cat: Current understanding and treatment approaches. Journal of Feline Medicine Surgery. 15(5), 401DOI: https://doi.org/10.1177\%2F1098612X13483238

23. Nespeca, G., Grest, P., Rosenkrantz, W. S., Ackermann, M. \& Favrot, C. (2006). Detection of novel papillomaviruslike sequences in paraffin-embedded specimens of invasive and in situ squamous cell carcinomas from cats. American Journal of Veterinary Research. 67(12), 2036DOI: https://doi.org/10.2460/ajvr.67.12.2036

24. O'Neill, S. H., Newkirk, K. M., Anis, E. A., Brahmbhatt, R., Frank, L. A. \& Kania, S. A. (2011). Detection of human papillomavirus DNA in feline premalignant and invasive squamous cell carcinoma. Veterinary Dermatology. 22(1), 68- DOI: https://doi.org/10.1111/j.1365-3164.2010.00912.x

25. Oh, Y.-I., Cheon, D.-S., Lee, J.-K., Choi, M.-H., Hwang, S.-Y., Kim, H.-W., Kang, B.-J. \& Youn, H.-Y. (2018). Detection of Felis catus papillomavirus type 2 within multicentric basosquamous carcinoma in a domestic cat. The Journal of Veterinary Medical Science. 80, 1445-

DOI: https://doi.org/10.1292/jvms.17-0702

26. Ohtani, N., Yamakoshi, K., Takahashi, A. \& Hara, E. (2004). The p16INK4a-RB pathway: molecular link between cellular senescence and tumor suppression. The Journal of Medical Investigation. 51, 146DOI: https://doi.org/10.2152/imi.51.146

27. Parry, D., Bates, S., Mann, D. J. \& Peters, G. 1995. Lack of cyclin D-Cdk complexes in Rb-negative cells correlates with high levels of $\mathrm{p} 16 \mathrm{INK} 4 / \mathrm{MTS1}$ tumour suppressor gene product. The EMBO Journal. 14, 503- DOI: https://doi.org/10.1002/i.1460-2075.1995.tb07026.x

28. Ranieri, G., Pantaleo, M., Piccinno, M., Roncetti, M., Mutinati, M., Marech, I., Patruno, R., Rizzo, A. \& Sciorsci, R. L. (2013). Tyrosine kinase inhibitors (TKIs) in human and pet tumours with special reference to breast cancer: A comparative review. Critical Reviews in Oncology/Hematology. 88, 293DOI: https://doi.org/10.1016/i.critrevonc.2013.05.009

29. Sauer, U. G., Vogel, S., Hess, A., Kolle, S. N., Ma-Hock, L., Van Ravenzwaay, B. \& Landsiedel, R. (2013). In vivo-in vitro comparison of acute respiratory tract toxicity using human 3D airway epithelial models and human A549 and murine 3 T3 monolayer cell systems. Toxicology in Vitro. 27(1), 174DOI: https://doi.org/10.1016/i.tiv.2012.10.007

30. Song, J. W. \& Chung, K. C. (2010). Observational Studies: Cohort and Case-Control Studies. Plastic and Reconstructive Surgery. 126, 2234- DOI: https://doi.org/10.1097/prs.0b013e3181f44abc 
31. Thomson, N. A., Howe, L., Weidgraaf, K., Thomas, D. G., Young, V., Ward, V. K. \& Munday, J. S. (2019). Felis catus papillomavirus type 2 virus-like particle vaccine is safe and immunogenic but does not reduce FcaPV-2 viral loads in adult cats. Veterinary Immunology and Immunopathology. 213, DOI: https://doi.org/10.1016/i.vetimm.2019.109888

32. Thomson, N. A., Munday, J. S. \& Dittmer, K. E. (2016). Frequent detection of transcriptionally active Felis catus papillomavirus 2 in feline cutaneous squamous cell carcinomas. Journal of General Virology. 97(5), 1189- DOI: https://doi.org/10.1099/igv.0.000416

33. Wilczynski, S. P., Lin, B. T., Xie, Y. \& Paz, I. B. (1998). Detection of human papillomavirus DNA and oncoprotein overexpression are associated with distinct morphological patterns of tonsillar squamous cell carcinoma. American Journal of Pathology. 152, 145-156. 


\section{EVIIDEFeE

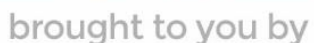 \\ RCVS KNOWLEDGE}

\section{Intellectual Property Rights}

Authors of Knowledge Summaries submitted to RCVS Knowledge for publication will retain copyright in their work, and will be required to grant RCVS Knowledge a non-exclusive license of the rights of copyright in the materials including but not limited to the right to publish, republish, transmit, sell, distribute and otherwise use the materials in all languages and all media throughout the world, and to license or permit others to do so.

\section{Disclaimer}

Knowledge Summaries are a peer-reviewed article type which aims to answer a clinical question based on the best available current evidence. It does not override the responsibility

of the practitioner. Informed decisions should be made by considering such factors as individual clinical expertise and judgement along with patient's circumstances and owners' values. Knowledge Summaries are a resource to help inform and any opinions expressed within the Knowledge Summaries are the author's own and do not necessarily reflect the view of the RCVS Knowledge. Authors are responsible for the accuracy of the content. While the

Editor and Publisher believe that all content herein are in accord with current recommendations and practice at the time of publication, they accept no legal responsibility

for any errors or omissions, and make no warranty, express or implied, with respect to material contained within.

For further information please refer to our Terms of Use.

RCVS Knowledge is the independent charity associated with the Royal College of Veterinary Surgeons (RCVS). Our ambition is to become a global intermediary for evidence based veterinary knowledge by providing access to information

that is of immediate value to practicing veterinary professionals and directly contributes to evidence based clinical decision-making.

\section{https://www.veterinaryevidence.org/}

RCVS Knowledge is a registered Charity No. 230886.

Registered as a Company limited by guarantee in England and Wales No. 598443.

Registered Office: Belgravia House, 62-64 Horseferry Road, London SW1P 2AF

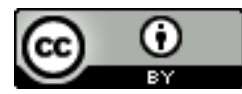

This work is licensed under a Creative Commons Attribution 4.0 International License. 